\title{
Brazilian version of the Berg balance scale
}

S.T. Miyamoto ${ }^{1}$ I. Lombardi Junior ${ }^{1}$, K.O. Berg',

L.R. Ramos ${ }^{2}$ and J. Natour ${ }^{1}$

\author{
Disciplinas de ${ }^{1}$ Reumatologia and ${ }^{2}$ Geriatria, Escola Paulista de Medicina, \\ Universidade Federal de São Paulo, São Paulo, SP, Brasil \\ ${ }^{3}$ Division of Physical and Occupational Therapy, McGill University, \\ Montreal, Canada
}

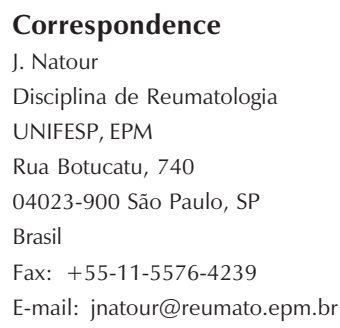

Received July 28, 2003

Accepted April 13, 2004

\begin{abstract}
The purpose of the present study was to translate and adapt the Berg balance scale, an instrument for functional balance assessment, to Brazilian-Portuguese and to determine the reliability of scores obtained with the Brazilian adaptation. Two persons proficient in English independently translated the original scale into Brazilian-Portuguese and a consensus version was generated. Two translators performed a back translation. Discrepancies were discussed and solved by a panel. Forty patients older than 65 years and 40 therapists were included in the cultural adaptation phase. If more than $15 \%$ of therapists or patients reported difficulty in understanding an item, that item was reformulated and reapplied. The final Brazilian version was then tested on 36 elderly patients (over age 65). The average age was 72 years. Reliability of the measure was assessed twice by one physical therapist (1-week interval between assessments) and once by one independent physical therapist. Descriptive analysis was used to characterize the patients. The intraclass correlation coefficient (ICC) and Pearson's correlation coefficient were computed to assess intra- and interobserver reliability. Six questions were modified during the translation stage and cultural adaptation phase. The ICC for intra- and interobserver reliability was $0.99(\mathrm{P}<0.001)$ and $0.98(\mathrm{P}<0.001)$, respectively. The Pearson correlation coefficient for intra- and interobserver reliability was $0.98(\mathrm{P}<0.001)$ and $0.97(\mathrm{P}<0.001)$, respectively. We conclude that the Brazilian version of the Berg balance scale is a reliable instrument to be used in balance assessment of elderly Brazilian patients.
\end{abstract}

\section{Introduction}

The ability to maintain balance or postural control is important for the correct execution of all daily tasks ranging from standing and walking to sitting and rising from a chair (1). Possessing the ability to maintain various
Key words

- Balance

- Outcome assessment

- Disability evaluation

- Rehabilitation

- Geriatric patients

- Postural control positions, to respond automatically to voluntary movements of the body and extremities, and to react to external perturbations represents a postural control domain required in daily life (2), and can be measured by some instruments for functional balance assessment (3-9) such as the Berg balance scale 
(2). However, no report regarding instruments for functional balance assessment is available in the Portuguese language in the scientific literature.

The Berg balance scale (2) assesses functional balance performance based on 14 items common to daily life. The maximum score that can be reached is 56 and each item possesses an ordinal scale of five alternatives ranging from 0 to 4 points. The test is simple, easy to administer and safe for the evaluation of elderly patients. It only requires a watch and a ruler as equipment and takes approximately $15 \mathrm{~min}$ to perform.

The scale is used to assess frail elderly individuals and patients with balance deficits referred for rehabilitation, regardless of age. The test satisfies various requirements, including quantitative balance descriptions, monitoring of the patient's progress and assessment of the efficacy of interventions carried out in clinical practice and in research (2).

Correlations of the Berg balance scale with global indices of other assessment instruments (0.47 to 0.61$)$, self-indices of the elderly ( 0.39 to 0.41 ) and laboratory oscillation measures (response to external perturbations: -0.38 to spontaneous oscillation: -0.55 ) are moderately strong and statistically significant (10). High correlations have been observed between the Berg balance scale and the Balance Sub-Scale developed by Tinetti $(r=0.91)$, the Barthel Mobility Sub-Scale ( $r$ $=0.67)$ and the Timed Up \& Go Test $(r=$ 0.76) (10). Liston and Brouwer (11) obtained a strong correlation $(\mathrm{r}=0.81, \mathrm{P}<$ $0.0001)$ between the Berg balance scale and the dynamic balance measures obtained using the Balance Master, a computerized instrument for balance assessment and training.

The inter- and intraobserver reliability of the Berg balance scale was 0.98 and 0.99, respectively, and it also showed a high degree of internal consistency (Cronbach's $\alpha$ 0.96), indicating that the scale is measuring one concept and that the overall scale is providing more information on balance than any one item (2). Determination of the reliability of the scale in another study conducted on institutionalized elderly individuals and patients hospitalized with an acute diagnosis of cardiovascular accident (CVA) also showed excellent inter- (intraclass correlation coefficient, $\mathrm{ICC}=0.98$ ) and intraobserver (ICC $=0.97)$ agreement. Internal consistency was high in both institutionalized elderly individuals $(\alpha>0.83)$ and patients with CVA $(\alpha>0.97)$ (12).

According to Thorbahn and Newton (13), the Berg balance scale possesses $82 \%$ sensitivity and $87 \%$ specificity, while ShumwayCook et al. (14) found 55\% sensitivity and 95\% specificity for the accuracy of identifying a failure. The latter investigators demonstrated that the best model to predict falls, considering a cut-off score of 45 , is a combination of two factors, i.e., the score of the Berg balance scale and a self-reported history of imbalance, showing $91 \%$ sensitivity and $82 \%$ specificity. Harada et al. (15) found $91 \%$ sensitivity and $70 \%$ specificity for a combination of the Berg balance scale with gait speed using a cut-off score of 48 .

The purpose of the present study was to translate and cross-culturally adapt the Berg balance scale to a Brazilian elderly population and to assess its reliability based on the evidence supporting its measurement properties.

\section{Patients and Methods}

Seventy-six patients older than 65 years were selected consecutively from the Rheumatology Outpatient Clinic, Universidade Federal de São Paulo, Escola Paulista de Medicina (UNIFESP-EPM). Forty patients were selected for the cultural adaptation process and 36 for assessment of the reliability of the Berg balance scale. Patients who were unable to stand independently on their feet, patients using lower limb prostheses and patients with lower limb amputations 
were excluded from the study.

During the cultural adaptation process, 4 occupational therapists and 36 physical therapists of UNIFESP-EPM, who were unaware of the scale, were also selected to apply the instrument to another person, since the scale requires an interpretation by the therapist in relation to the task to be performed (instructions) by the patient and to the score of each item (response alternatives).

Initial translation and evaluation of the initial translation (back translation)

The Berg balance scale was initially translated by two persons proficient in English whose native language was Portuguese after the objective of the study was explained to them. The two translations were compared and when differences were identified, the texts were modified to obtain consensus between the two translations regarding the initial translation.

The consensus Portuguese version was again translated into English by two other English teachers whose native language was English and who were unaware of the original version and of the objective of the study.

The two English versions were compared with the original English translation. The differences were analyzed, and questions and/or response choices were rewritten when necessary, thus providing a second Portuguese version.

All the misunderstood items were replaced and discrepancies were resolved by a multidisciplinary and bilingual committee (16) composed of two physical therapists, an occupational therapist and a physician.

\section{Evaluation of cultural equivalence}

The second Portuguese version was then applied to 20 patients. The expression "I do not understand" was added to the instructions. Questions receiving more than $15 \%$ "I do not understand" responses were analyzed and replaced with other items of the same concept, so that the assessment structure and properties of these questions would not be significantly altered. After modification, this third version was again applied to another group of 20 patients and its cultural equivalence was again tested until no item was considered not understandable by more than $15 \%$ of the patients.

The third version was also given to two occupational therapists and 18 physical therapists specialized in the areas of rheumatology, orthopedics and neurology, so that they could apply the scale to another person in order to test his/her understanding in terms of the instruction and response alternatives for each question. Questions with more than $15 \%$ incomprehension with respect to both the instruction and response alternatives were again discussed and the items were modified. This fourth version was given to another group of two occupational therapists and 18 physical therapists specialized in the areas of rheumatology, orthopedics and neurology until no item was considered not understandable by more than $15 \%$ of the therapists.

\section{Reliability}

To test the reliability of the Brazilian version of the Berg balance scale, the scale (final version) was applied to 36 patients during three assessments. The first two assessments were performed consecutively on the same day by two observers (interobserver reliability), at an interval of approximately $15 \mathrm{~min}$, with either observer 1 or observer 2 applying the first assessment, thus preventing a habituation bias in terms of the tasks performed by the patients obeying immediately the commanding voice of the observer. The third assessment was applied after seven days at the same time by observer 1 (intraobserver reliability).

On the same day personal data and data related to the study such as diagnosis, use of medication, number of falls during the last 6 
months, number of previous fractures, and type of locomotion aid were collected.

A digital chronometer, a $30-\mathrm{cm}$ ruler, a 20-cm high stool, a 42-cm high chair with a backrest and no armrest, and a 42-cm high chair with a backrest and armrest were used for the assessment.

\section{Statistical analysis}

Descriptive statistical analysis was used for the clinical-demographic characterization of the patients included in the phase of reliability assessment. Inter- and intraobserver reliability of the final Brazilian version of the Berg balance scale was determined by Pearson's correlation coefficient and by the ICC (parallel; one-way random effect model; $95 \% \mathrm{CI}$ ). The main variable of interest was the total score of the Berg balance scale (0 to 56).

\section{Results}

\section{Translation and cultural adaptation}

In the second version of the scale, questions $3,6,10,11$, and 13 were considered

\begin{tabular}{|c|c|c|c|}
\hline Question & $\begin{array}{l}\text { Number of } \\
\text { patients who did } \\
\text { not understand } \\
\text { the question (\%) }\end{array}$ & $\begin{array}{l}\text { Number of occupational } \\
\text { and physical therapists } \\
\text { who did not understand } \\
\text { the statement }(\%)\end{array}$ & $\begin{array}{l}\text { Number of occupational } \\
\text { and physical therapists who } \\
\text { did not understand the } \\
\text { alternative response (\%) }\end{array}$ \\
\hline 1 & 0 & 0 & 0 \\
\hline 2 & 0 & 0 & $7(35)^{*}$ \\
\hline 3 & $20(100)^{*}$ & 0 & $7(35)^{*}$ \\
\hline 4 & 0 & 0 & 0 \\
\hline 5 & 0 & $20(100)$ & $7(35)^{*}$ \\
\hline $6 *$ & $7(35)^{*}$ & 0 & $7(35)^{*}$ \\
\hline 7 & 0 & 0 & $7(35)^{*}$ \\
\hline 8 & 0 & $2(10)$ & $7(35)^{*}$ \\
\hline 9 & 0 & 0 & $7(35)^{*}$ \\
\hline 10 & $8(40)^{*}$ & 0 & $7(35)^{*}$ \\
\hline 11 & $5(25)^{*}$ & 0 & $7(35)^{*}$ \\
\hline 12 & $2(10)$ & 0 & 0 \\
\hline 13 & $6(30)^{*}$ & $16(80)^{*}$ & $16(80)^{*}$ \\
\hline 14 & 0 & 0 & 0 \\
\hline
\end{tabular}

*Questions that were modified as a result of the evaluations. "incomprehensible" by more than $15 \%$ of the patients studied (20 patients, Table 1, column 1). These questions were modified and a third version was again administered to another group of 20 patients in order to determine its comprehension and cultural equivalence. After these modifications, the questions were understood by $100 \%$ of the patients.

When the third version was presented to two occupational therapists and 18 physical therapists, more than $15 \%$ did not understand the following three items (Table 1, columns 2 and 3): the term "supervisão" (supervision) in the response alternatives for questions 2, 3, 5, 6, 7, 8, 9, 10, and 11, the instruction of question 5, and the instruction and response alternatives " 3 points" of question 13. After these modifications, a fourth version (final version) was generated and the questions were considered comprehensible by $100 \%$ of the therapists when administered by another group of two occupational therapists and 18 physical therapists.

\section{Reliability}

Seventy-five percent of the 36 patients older than 65 years included in the evaluation of the reliability of the final Brazilian version of the Berg balance scale were females and $25 \%$ were males. The mean age was 72 years (range 65 to 83 years). Most patients were literate $(80.51 \%)$, but $72.41 \%$ had less than 5 years of schooling. Only $17 \%$ of the patients practiced some type of regular physical activity, considered to be a minimum of three times a week. Some type of locomotion aid was used by $31 \%$ of the patients (a walking stick by 10 and a walker/wheel chair by 1), with the mean number of falls during the last 6 months being $1.22(0-10)$ and the mean number of previous fractures being 0.64 ( 0 $3)$. Rheumatic disorders were observed in 29 patients, visual deficits in 27, cardiovascular diseases in 19 , metabolic diseases in 6, neurological disturbances in 3 , lung diseases in 
2, and gastrointestinal disorders in 1. Eighteen patients had a diagnosis of osteoporosis.

The mean total score obtained for the first application of the final version was 49.9 (range 8 to 56 points) of a total of 56 points.

Table 2 shows the results of intra- and interobserver reliability for each question and for the total score using the ICC. The intraand interobserver reliabilities for the total score of the scale calculated by Pearson's correlation coefficient were $0.984(\mathrm{P}<0.01)$ and $0.975(\mathrm{P}<0.01)$, respectively.

\section{Discussion}

According to Guillemin et al. (16), for a previously validated assessment instrument to be used in different countries whose language is not the original language of the instrument, it is necessary to translate and adapt the instrument to the language and culture of the country in question following some predefined criteria, since producing a new instrument becomes expensive and unnecessary when an instrument with the same objective and of good quality is already available.

The Berg balance scale was originally written in English with questions pertaining to the Canadian culture. Therefore, in order to apply the scale to the Brazilian population, we tested the instrument in terms of cultural equivalence so that it could be well interpreted by both the patient and the examiner (see Appendix 1).

The usefulness of the Berg balance scale for the assessment of functional balance has been confirmed in research studies and in clinical practice based on the extensive analysis of its measure properties which were found to be reliable $(2,10-15)$. Thus, its translation into Brazilian-Portuguese should contribute to the scientific community and will help in the rehabilitation of Brazilian individuals with balance disturbances.

The stages of initial translation and evaluation of the initial translation (back transla- tion) did not show important differences between the translators and the review committee. However, various problems related to both patients and occupational and physical therapists were detected during the cultural adaptation phase.

In question 3, the specific instruction is that the patient should remain seated with back unsupported. However, in the instruction given to the patient the backrest is omitted, leading to the fact that all patients performed the task in an inadequate manner, and therefore the term "apoio nas costas" (backrest) was also included in the instructions to prevent the possibility of omission of this fundamental aspect of the task by therapists applying the instrument.

In question 6, the instructions indicate that the patient closes his/her eyes and stands still for $10 \mathrm{~s}$, which leads to the fact that the patients close their eyes before standing up from the chair, provoking a risk of fall while the objective of the task is that the patient simply remains standing with his/her eyes

Table 2. Intra- and interobserver reliability obtained for each item and for the total score of the Brazilian version of the Berg balance scale as determined by the intraclass correlation coefficient.

\begin{tabular}{ccc}
\hline & \multicolumn{2}{c}{ Intraclass correlation coefficient } \\
\cline { 2 - 3 } & Intraobserver & Interobserver \\
\hline 1 & 1 & 0.9748 \\
2 & 0.6569 & 0.7019 \\
3 & $*$ & $*$ \\
4 & 0.9955 & 0.9178 \\
5 & 0.9844 & 0.9516 \\
6 & 0.6886 & 0.5551 \\
7 & 0.8083 & 0.5545 \\
8 & 0.9488 & 0.9258 \\
9 & 0.9900 & 0.9795 \\
10 & 0.9116 & 0.8662 \\
11 & 0.9557 & 0.839 \\
12 & 0.9721 & 0.9756 \\
13 & 0.8751 & 0.785 \\
14 & 0.9169 & 0.8776 \\
Total score & 0.9917 & 0.9856 \\
\hline Not possible to calculate because this variable is \\
constant. & & \\
& &
\end{tabular}


closed. Changing the order of the words by asking the patient to stand and close his/her eyes for $10 \mathrm{~s}$ solved the problem. However, the problem might have been the result of the fact that the previous question ended with the patient sitting, so that the patient had to stand up to begin the task of question 6. If the patient had been standing, the instruction "feche os olhos e fique em pé por 10 segundos" (close your eyes and stand still for $10 \mathrm{~s}$ ) would have probably been performed without problems.

In contrast, in question 10, the expression "sem tirar os pés do chão" (without lifting your feet from the floor) was added because some patients rotate by moving their feet, since the verbs "virar" and "girar" are often used as synonyms by the Brazilian population, with the objective of the task being to keep one's balance by maintaining the feet firmly on the floor while looking behind. The task to turn completely around in a full circle (question 11) raised doubts during its execution due to the expression "ao redor de um círculo completo", which popularly refers to "ao redor de si mesmo" (around yourself).

The instruction to question 13 "coloque um pé em frente ao outro. Se você achar que não irá conseguir colocar um pé diretamente na frente do outro, tente dar um passo a uma distância tal que o calcanhar do pé da frente esteja um pouco mais à frente dos dedos do outro pé" (place one foot directly in front of the other. If you feel that you cannot place your foot directly in front, try to step far enough ahead that the heel of your forward foot is ahead of the toes of the other foot), considered to be complex by $30 \%$ of the patients, was simplified to "coloque um pé diretamente à frente do outro na mesma linha, se você achar que não irá conseguir, coloque o pé um pouco mais à frente do outro pé e levemente para o lado" (place one foot directly in front of the other on the same line; if you think you are unable, place the foot slightly ahead and to the side of the other foot).

The term "supervisão" (supervision) in the response alternatives $2,3,5,6,7,8,9$, 10 , and 11 was questioned by $35 \%$ of the therapists. To some, supervision meant only observing, from near or far, to others it meant providing some support, while the real meaning of the term was that the examiner is required to stay close to the patient, but without touching him/her, which was added to the general instructions.

In the instructions to question 5 , the term "pivô" (pivot), which is not used frequently in daily clinical practice by Brazilian therapists, raised doubts regarding the position of the chairs for the execution of the task. Positioning of the chairs, either perpendicular to or one in front of the other, permits the reproduction of an imbalance effect when performing pivot transfer.

Question 13 was found to be difficult to understand on the part of the therapists in terms of scoring ( 3 points), since the instruction is that "para marcar 3 pontos, o comprimento da passada deverá exceder o comprimento do outro pé e a largura do passo deverá ser aproximadamente a do passo normal do paciente" (to score 3 points, the length of the step should exceed the length of the other foot and the width of the stance should approximate the subject's normal stride width), while the response alternative to score 3 points states that the patient should be "capaz de colocar um pé na frente do outro, sozinho, permanecendo por 30 segundos" (able to place foot ahead of other independently and hold $30 \mathrm{~s}$ ). For some, the front foot should be slightly on the side of the other foot by the width of a normal step after passing the foot in back, while for others the front foot should be exactly in front of the other foot, but slightly to the side and ahead, which is the correct position. This problem of idiomatic equivalence and vocabulary was solved by simplifying the question. The recommendation to score 3 points was eliminated from the instruction, the statement 
modified to "coloque um pé diretamente à frente do outro na mesma linha, se você achar que não irá conseguir, coloque o pé um pouco mais à frente do outro pé e levemente para o lado" (place one foot directly in front of the other on the same line; if you think you are unable, place the foot slightly ahead and to the side of the other foot), and the alternative to score 3 points was altered to "capaz de colocar um pé um pouco mais à frente do outro e levemente para o lado, independentemente, permanecendo por 30 segundos" (able to independently place the foot slightly ahead and to the side of the other, remaining in this position for $30 \mathrm{~s}$ ).

The determination of the reliability of the Portuguese translation of the Berg balance scale indicate that significantly high intraand interobserver correlations were observed for all components. The intraobserver ICC for each item ranged from 0.65 to 0.99 and the intraobserver ICC for total score was 0.99 , values similar to those obtained by Berg et al. (2), who reported an ICC ranging from 0.71 to 0.99 for each item and an ICC of 0.99 for total score. A similar ICC of 0.97 for total score was also reported in another study by Berg et al. (12) conducted on institutionalized elderly individuals and patients hospitalized with a diagnosis of acute CVA. In that study, interobserver reliability ranged from 0.55 to 0.97 for each item and was 0.98 for total score, with these values also being similar to those reported by Berg in 1989 (2) (0.71 to 0.99 for each item and 0.98 for total score) and in 1995 (12) (0.98 for total score).

In research, any reliability error might influence sample size and effort to detect the true effect of treatment. In contrast, in clinical practice, when repeated tests are used for clinical decisions, a reliability index above 0.94 is recommended (17). The high reliability indices found in the present study indicate the usefulness of the scale both for research and clinical practice.

No studies are available regarding the reliability of the Balance Coding Scale (6) or CTSIB (18), or regarding intraobserver reliability and internal consistency of the Tinetti Balance Sub-Scale $(3,19,20)$. The Functional Reach Test demonstrated excellent interobserver reliability and test-retest results for individuals independently standing on their feet, but it only considers one very restricted balance item, a fact that renders this test insufficient $(21,22)$. In contrast, the Berg balance scale demonstrated high reliability under various real clinical conditions at different times of day, in different places and also under different situations of noise and distraction. In addition, this scale has been validated $(10,23)$. The Berg balance scale also more efficiently discriminated groups of elderly individuals using different locomotion aids than the Tinetti Balance SubScale (23). Furthermore, the only instrument, besides the Berg balance scale, that has been shown to be sensitive to changes in balance status was the functional reach test (24), which is one of the items of the Berg balance scale.

As was the case for the validation of the Berg balance scale (10), the present study involved more women than men, and the most common co-morbidities were, in decreasing order, rheumatic diseases, visual disorders, and cardiovascular and neurological diseases. The mean age of the present population was approximately 10 years lower than that of the population in the original publication (10).

In summary, we have shown here that the Brazilian version of the Berg balance scale is a reliable instrument for the assessment of functional balance in Brazilian elderly individuals. 


\section{References}

1. Schultz AB, Alexander NB \& Ashton-Miller JA (1992). Biomechanical analyses of rising from a chair. Journal of Biomechanics, 25: 1381-1391.

2. Berg K, Wood-Dauphinée S, Williams JI \& Gayton D (1989). Measuring balance in the elderly: preliminary development of an instrument. Physiotherapy Canada, 41: 304-311.

3. Tinetti ME (1986). Performance-oriented assessment of mobility problems in the elderly patients. Journal of the American Geriatrics Society, 34: 119-126.

4. Reuben DB \& Siu AL (1990). An objective measure of physical function of elderly outpatients. Journal of the American Geriatrics Society, 38: 1105-1112.

5. DiFabio RP \& Seay R (1997). Use of the "Fast evaluation of mobility, balance, and fear" in elderly community dwellers: validity and reliability. Physical Therapy, 77: 904-917.

6. Gabell A \& Simons MA (1982). Balance coding. Physiotherapy, 68: 286-288.

7. Wolfson LI, Whipple R, Amerman P \& Kleinberg A (1986). Stressing the postural response: a quantitative method for testing balance. Journal of the American Geriatrics Society, 34: 845-850.

8. Hamilton BB, Laughlin JA, Fieldler RC \& Granger CV (1994). Interrater reliability of the 7-level functional independence measure (FIM). Scandinavian Journal of Rehabilitation Medicine, 26: 115119.

9. Means KM (1996). The obstacle course: a tool for the assessment of functional balance and mobility in the elderly. Journal of Rehabilitation Research and Development, 33: 413-428.

10. Berg KO, Wood-Dauphinée S, Williams JI \& Maki B (1992). Measuring balance in the elderly: validation of an instrument. Canadian Journal of Public Health, 83 (Suppl 2): S7-S11.

11. Liston RAL \& Brouwer BJ (1996). Reliability and validity of measures obtained from stroke patients using the Balance Master. Archives of Physical Medicine and Rehabilitation, 77: 425-430.

12. Berg KO, Wood-Dauphinée S \& Williams JI (1995). The balance scale: reliability assessment with elderly residents and patients with an acute stroke. Scandinavian Journal of Rehabilitation Medicine,
27: 27-36.

13. Thorbahn LDB \& Newton RA (1996). Use of the Berg Balance Test to predict falls in elderly persons. Physical Therapy, 76: 576-585.

14. Shumway-Cook A, Baldwin M, Polissar NL \& Gruber W (1997). Predicting the probability for falls in community-dwelling older adults. Physical Therapy, 77: 812-819.

15. Harada U, Chiu V, Damon-Rodriguez J, Fowler E, Siu A \& Reuben DB (1995). Screening for balance and mobility impairment in elderly individual living in residential care facilities. Physical Therapy, 75: 462-469.

16. Guillemin F, Bombardier C \& Beaton D (1993). Cross-cultura adaptation of health-related quality of life measures: literature review and proposed guidelines. Journal of Clinical Epidemiology, 46: 1417-1432.

17. Helmstadter GC (1964). Principles of Psycological Measurement Appleton-Century-Crofts, New York.

18. Horak FB (1987). Clinical measurement of postural control in adults. Physical Therapy, 67: 1881-1885.

19. Shumway-Cook A \& Horak FB (1986). Assessing the influence of sensory interaction on balance. Physical Therapy, 66: 1548-1550.

20. Tinetti ME, Williams TF \& Mayewski R (1986). Fall risk index for elderly patients based on number of chronic disabilities. American Journal of Medicine, 80: 429-434.

21. Duncan PW, Weiner DK, Chandler J \& Studenski S (1990). Functional reach: a new clinical measure of balance. Journal of Gerontology, 45: M192-M197.

22. Duncan PW, Studenski S, Chandler J \& Prescott B (1992). Functional reach: predictive validity in a sample of elderly male veterans. Journal of Gerontology, 47: M93-M98.

23. Berg KO, Maki B, Williams JI, Holliday PJ \& Wood-Dauphinée S (1992). Clinical and laboratory measures of postural balance in an elderly population. Archives of Physical Medicine and Rehabilitation. 73: 1073-1080.

24. Tinetti ME, Speechley M \& Ginter SF (1988). Risk factors for falls among elderly persons living in the community. New England Journal of Medicine, 319: 1701-1707. 


\title{
Appendix 1
}

\section{Brazilian-Portuguese version of the Berg balance scale}

\author{
Escala de equilíbrio funcional de Berg - Versão Brasileira
}

Nome

Data

Local

Avaliador

\section{Descrição do item ESCORE (0-4)}

1. Posição sentada para posição em pé

2. Permanecer em pé sem apoio

3. Permanecer sentado sem apoio

4. Posição em pé para posição sentada

5. Transferências

6. Permanecer em pé com os olhos fechados

7. Permanecer em pé com os pés juntos

8. Alcançar a frente com os braços estendidos

9. Pegar um objeto do chão

10. Virar-se para olhar para trás

11. Girar 360 graus

12. Posicionar os pés alternadamente no degrau

13. Permanecer em pé com um pé à frente

14. Permanecer em pé sobre um pé

Total

\section{Instruções gerais}

Por favor, demonstrar cada tarefa e/ou dar as instruções como estão descritas. Ao pontuar, registrar a categoria de resposta mais baixa, que se aplica a cada item.

$\mathrm{Na}$ maioria dos itens, pede-se ao paciente para manter uma determinada posição durante um tempo específico. Progressivamente mais pontos são deduzidos, se o tempo ou a distância não forem atingidos, se o paciente precisar de supervisão (o examinador necessita ficar bem próximo do paciente) ou fizer uso de apoio externo ou receber ajuda do examinador. Os pacientes devem entender que eles precisam manter o equilíbrio enquanto realizam as tarefas. As escolhas sobre qual perna ficar em pé ou qual distância alcançar ficarão a critério do paciente. Um julgamento pobre irá influenciar adversamente o desempenho e o escore do paciente.

Os equipamentos necessários para realizar os testes são um cronômetro ou um relógio com ponteiro de segundos e uma régua ou outro indicador de: $5 ; 12,5$ e $25 \mathrm{~cm}$. As cadeiras utilizadas para o teste devem ter uma altura adequada. Um banquinho ou uma escada (com degraus de altura padrão) podem ser usados para o item 12 .

\section{Posição sentada para posição em pé}

Instruções: Por favor, levante-se. Tente não usar suas mãos para se apoiar.

( ) 4 capaz de levantar-se sem utilizar as mãos e estabilizar-se independentemente

( ) 3 capaz de levantar-se independentemente utilizando as mãos

( ) 2 capaz de levantar-se utilizando as mãos após diversas tentativas

( ) 1 necessita de ajuda mínima para levantar-se ou estabilizar-se

( ) 0 necessita de ajuda moderada ou máxima para levantar-se

\section{Permanecer em pé sem apoio}

Instruções: Por favor, fique em pé por 2 minutos sem se apoiar.

( ) 4 capaz de permanecer em pé com segurança por 2 minutos

( ) 3 capaz de permanecer em pé por 2 minutos com supervisão

( ) 2 capaz de permanecer em pé por 30 segundos sem apoio

( ) 1 necessita de várias tentativas para permanecer em pé por 30 segundos sem apoio

( ) 0 incapaz de permanecer em pé por 30 segundos sem apoio

Se o paciente for capaz de permanecer em pé por 2 minutos sem apoio, dê o número total de pontos para o item No. 3. Continue com o item No. 4. 
3. Permanecer sentado sem apoio nas costas, mas com os pés apoiados no chão ou num banquinho Instruções: Por favor, fique sentado sem apoiar as costas com os braços cruzados por 2 minutos.

( ) 4 capaz de permanecer sentado com segurança e com firmeza por 2 minutos

( ) 3 capaz de permanecer sentado por 2 minutos sob supervisão

( ) 2 capaz de permanecer sentado por 30 segundos

( ) 1 capaz de permanecer sentado por 10 segundos

( ) 0 incapaz de permanecer sentado sem apoio durante 10 segundos

\section{Posição em pé para posição sentada} Instruções: Por favor, sente-se.

( ) 4 senta-se com segurança com uso mínimo das mãos

( ) 3 controla a descida utilizando as mãos

( ) 2 utiliza a parte posterior das pernas contra a cadeira para controlar a descida

( ) 1 senta-se independentemente, mas tem descida sem controle

( ) 0 necessita de ajuda para sentar-se

\section{Transferências}

Instruções: Arrume as cadeiras perpendicularmente ou uma de frente para a outra para uma transferência em pivô. Peça ao paciente para transferir-se de uma cadeira com apoio de braço para uma cadeira sem apoio de braço, e vice-versa. Você poderá utilizar duas cadeiras (uma com e outra sem apoio de braço) ou uma cama e uma cadeira.

( ) 4 capaz de transferir-se com segurança com uso mínimo das mãos

( ) 3 capaz de transferir-se com segurança com o uso das mãos

( ) 2 capaz de transferir-se seguindo orientações verbais e/ou supervisão

( ) 1 necessita de uma pessoa para ajudar

( ) 0 necessita de duas pessoas para ajudar ou supervisionar para realizar a tarefa com segurança

\section{Permanecer em pé sem apoio com os olhos fechados} Instruções: Por favor, fique em pé e feche os olhos por 10 segundos.

( ) 4 capaz de permanecer em pé por 10 segundos com segurança

( ) 3 capaz de permanecer em pé por 10 segundos com supervisão

( ) 2 capaz de permanecer em pé por 3 segundos

( ) 1 incapaz de permanecer com os olhos fechados durante 3 segundos, mas mantém-se em pé

( ) 0 necessita de ajuda para não cair

7. Permanecer em pé sem apoio com os pés juntos Instruções: Junte seus pés e fique em pé sem se apoiar.

( ) 4 capaz de posicionar os pés juntos independentemente e permanecer por 1 minuto com segurança

( ) 3 capaz de posicionar os pés juntos independentemente e permanecer por 1 minuto com supervisão

( ) 2 capaz de posicionar os pés juntos independentemente e permanecer por 30 segundos

( ) 1 necessita de ajuda para posicionar-se, mas é capaz de permanecer com os pés juntos durante 15 segundos

( ) 0 necessita de ajuda para posicionar-se e é incapaz de permanecer nessa posição por 15 segundos

\section{Alcançar a frente com o braço estendido permanecendo em pé}

Instruções: Levante o braço a $90^{\circ}$. Estique os dedos e tente alcançar a frente o mais longe possível. ( $\mathrm{O}$ examinador posiciona a régua no fim da ponta dos dedos quando o braço estiver a $90^{\circ}$. Ao serem esticados para frente, os dedos não devem tocar a régua. A medida a ser registrada é a distância que os dedos conseguem alcançar quando o paciente se inclina para frente o máximo que ele consegue. Quando possível, peça ao paciente para usar ambos os braços para evitar rotação do tronco).

( ) 4 pode avançar à frente mais que $25 \mathrm{~cm}$ com segurança

( ) 3 pode avançar à frente mais que $12,5 \mathrm{~cm}$ com segurança

( ) 2 pode avançar à frente mais que $5 \mathrm{~cm}$ com segurança

( ) 1 pode avançar à frente, mas necessita de supervisão

( ) 0 perde o equilíbrio na tentativa, ou necessita de apoio externo

\section{Pegar um objeto do chão a partir de uma posição em pé} Instruções: Pegue o sapato/chinelo que está na frente dos seus pés.

( ) 4 capaz de pegar o chinelo com facilidade e segurança

( ) 3 capaz de pegar o chinelo, mas necessita de supervisão

( ) 2 incapaz de pegá-lo, mas se estica até ficar a 2-5 cm do chinelo e mantém o equilíbrio independentemente 
( ) 1 incapaz de pegá-lo, necessitando de supervisão enquanto está tentando

( ) 0 incapaz de tentar, ou necessita de ajuda para não perder o equilíbrio ou cair

10. Virar-se e olhar para trás por cima dos ombros direito e esquerdo enquanto permanece em pé Instruções: Vire-se para olhar diretamente atrás de você por cima do seu ombro esquerdo sem tirar os pés do chão. Faça o mesmo por cima do ombro direito.

(O examinador poderá pegar um objeto e posicioná-lo diretamente atrás do paciente para estimular o movimento)

( ) 4 olha para trás de ambos os lados com uma boa distribuição do peso

( ) 3 olha para trás somente de um lado, o lado contrário demonstra menor distribuição do peso

( ) 2 vira somente para os lados, mas mantém o equilíbrio

( ) 1 necessita de supervisão para virar

( ) 0 necessita de ajuda para não perder o equilíbrio ou cair

\section{Girar 360 graus}

Instruções: Gire-se completamente ao redor de si mesmo. Pausa. Gire-se completamente ao redor de si mesmo em sentido contrário.

( ) 4 capaz de girar 360 graus com segurança em 4 segundos ou menos

( ) 3 capaz de girar 360 graus com segurança somente para um lado em 4 segundos ou menos

( ) 2 capaz de girar 360 graus com segurança, mas lentamente

( ) 1 necessita de supervisão próxima ou orientações verbais

( ) 0 necessita de ajuda enquanto gira

12. Posicionar os pés alternadamente no degrau ou banquinho enquanto permanece em pé sem apoio

Instruções: Toque cada pé alternadamente no degrau/banquinho. Continue até que cada pé tenha tocado o degrau/banquinho quatro vezes.

( ) 4 capaz de permanecer em pé independentemente e com segurança, completando 8 movimentos em 20 segundos

( ) 3 capaz de permanecer em pé independentemente e completar 8 movimentos em mais que 20 segundos

( ) 2 capaz de completar 4 movimentos sem ajuda

( ) 1 capaz de completar mais que 2 movimentos com o mínimo de ajuda

( ) 0 incapaz de tentar, ou necessita de ajuda para não cair

\section{Permanecer em pé sem apoio com um pé à frente}

Instruções: (demonstre para o paciente) Coloque um pé diretamente à frente do outro na mesma linha; se você achar que não irá conseguir, coloque o pé um pouco mais à frente do outro pé e levemente para o lado.

( ) 4 capaz de colocar um pé imediatamente à frente do outro, independentemente, e permanecer por 30 segundos

( ) 3 capaz de colocar um pé um pouco mais à frente do outro e levemente para o lado, independentemente, e permanecer por 30 segundos

( ) 2 capaz de dar um pequeno passo, independentemente, e permanecer por 30 segundos

( ) 1 necessita de ajuda para dar o passo, porém permanece por 15 segundos

( ) 0 perde o equilíbrio ao tentar dar um passo ou ficar de pé

\section{Permanecer em pé sobre uma perna}

Instruções: Fique em pé sobre uma perna o máximo que você puder sem se segurar.

( ) 4 capaz de levantar uma perna independentemente e permanecer por mais que 10 segundos

( ) 3 capaz de levantar uma perna independentemente e permanecer por 5-10 segundos

( ) 2 capaz de levantar uma perna independentemente e permanecer por mais que 3 segundos

( ) 1 tenta levantar uma perna, mas é incapaz de permanecer por 3 segundos, embora permaneça em pé independentemente

( ) 0 incapaz de tentar, ou necessita de ajuda para não cair

( ) Escore total (Máximo = 56) 